\section{AL-AZHAR}

Assiut Dental Journal
The Official Publication of The

Faculty of Dental medicine.

Al-Azhar Assiut Uniuersity.

Egypt

\title{
Analysis of The Gingival Biotype Based on The Measurement of Hard and Soft Dental Tissue Dimensions
}

\author{
Amr Mohamed Hassan Abd-Allah ${ }^{\text {*1, }}$ Mohamad Fouad Edrees ${ }^{1}$, Khalid Seddik Hassan ${ }^{1}$
}

Codex : 01/1901

Aadj@azhar.edu.eg

\section{KEYWORDS}

Buccal bone; $C B C T$;

Crown length, Gingiva,

Papillary height and Papillary

width

1. Department of Oral Medicine, Periodontology, Oral Diagnosis, and Dental Radiology, Faculty of Dentistry, Al-Azhar University, Assiut

* Corresponding author e-mail: amrabdala.19@azhar.edu.eg

\section{ABSTRACT}

\section{ABSTRACT}

Aim: It is to determine the relationship between gingival thickness and (buccal bone thickness, crown length, crown width, papillary height and papillary width) at upper central incisors teeth by means of a noninvasive and relatively accurate digital registration method. Subjects and Methods: In 100 periodontally healthy subjects, cone-beam computed tomographic images were obtained. Measurements of buccal bone thickness and gingival thickness at the central incisors was performed at points $1 \mathrm{~mm}$ from the alveolar crest. Correlation coefficient was calculated to assess the correlation between gingival thickness and buccal bone thickness. Results: The mean and standard deviation values were calculated for each group. Pearson correlation was used to find the correlation between Gingival thickness and each of Bone thickness, Crown length, Crown width, Papillary height and Papillary width. Independent sample t-test was used to compare between females and males' results in each variable. The significance level was set at $\mathrm{p} \leq 0.05 \mathrm{~A}$ statistically significant difference was found between females and males in all variables Gingival thickness, Bone thickness, Crown length, Crown width, Papillary height and Papillary width where ( $p<0.001),(p<0.001),(p=0.001),(p=0.027)$, $(p=0.036)$ and $(p<0.001)$ respectively, where females always showed thin type. There was a significant positive relationship between gingival thickness and Bone thickness, which states that increasing gingival thickness will be accompanied by increasing in bone thickness and vice versa. Conclusion: there are significant correlation between the gingival biotype, bone thickness, Crown length, crown width and papilla of anterior incisor crowns and respectively were females always showed thin biotype than males.

\section{INTRODUCTION}

Knowledge of the periodontal biotype or phenotype is of fundamental importance to an oral clinician because the anatomical characteristics of the periodontium, such as gingival thickness, gingival width and alveolar bone morphology, will determine the behavior of periodontium when 
submitted to physical, chemical, or bacterial insult or during therapeutic procedures via periodontal surgeries implant ${ }^{1}$ and ${ }^{2}$ orthodontic treatment ${ }^{3}$. A direct correlation exists between gingival biotype and susceptibility to gingival recession following surgical and restorative procedures ${ }^{4}$.

Already in 1969, a close relationship was reported between the osseous architecture and the morphology of the gingiva in healthy subjects ${ }^{5}$. A variation in periodontal morphology between subjects and at different teeth was described: a pronounced, scalloped architecture versus a rather flat architecture combined with teeth with a square tooth form. This variation in morphology was categorized by creating two different periodontal entities, or so-called "biotypes": the thin, highly scalloped biotype on the one hand; the thick, flat biotype on the other. A possible relation between the shape and form of a tooth and its surrounding periodontium was suggested ${ }^{6,7}$

It has been suggested that besides the gingival morphology, the thickness of the alveolar bone is related to the form of the tooth as well ${ }^{8}$.

In recent years, several research groups have quantified the buccal bone thickness by means of Cone Beam CT (CBCT) scans ${ }^{9-11}$. More recently, a study on hard and soft tissue thickness of maxillary front teeth was published. Non-invasive CBCT scans were used to measure the buccal bone thickness while minimally invasive ${ }^{12}$.

As a clinician, one cannot be too careful in fully understanding the anatomy and morphology of the tissues as these may greatly influence the (aesthetic) outcome of certain treatments ${ }^{13-15}$. Successful restorations should therefore look like natural teeth as much as possible. A substantial part of this success is nowadays attributed to the appearance of the soft tissues. The level of the gingival margin, influencing the crown length, its texture and color are crucial for the aesthetic qualities. These features are highly influenced by soft tissue thickness. It is therefore of great importance to be able to correctly assess the thickness of the periodontal tissues ${ }^{16-18}$.

The most commonly used methods to assess the thickness of hard and soft tissue are: use of visual inspection, transparency of a periodontal probe, calipers in extraction sockets ${ }^{19}$ and more recently CBCT scans ${ }^{19-22}$

The use of CBCT scans to measure soft tissue thickness has been evaluated and compared to direct measurements with calipers in fresh extraction sockets and deemed satisfactory ${ }^{3}$. Ultimately, the use of an ultra-sonic device has proven to give accurate data, but is not suited to detect minor changes ${ }^{23}$.

\section{SUBJECT AND METHODS}

Among patients who visited a radiographic center for CBCT as a diagnostic tool for different causes 100 patients of both sex (75males and 25 females ranged in age from 21-46 years with a mean of 39.7 years, A clinical examination was done to all patients.

Whom all maxillary front teeth showed no signs of marginal or periapical bone loss was included. The following exclusion criteria were applied: 1) pregnant women; patients with systemic disease or who were taking medication that may have affected soft tissue thickness, such as calcium channel blockers or immunosuppressive drugs; 2) patients with fixed partial dentures or orthodontic appliances; 3) and 4) patients with signs of either periodontal disease, defined as a periodontal probing depth $>3 \mathrm{~mm}$, or gingival recession.

\section{Clinical parameters}

Which concern the maxillary central incisors and adjacent gingiva using a William's graduated periodontal probe and the results were assessed to the nearest $0.5 \mathrm{~mm}$, which include: Clinical crown length Crown width Papillary height and Papillary width Fig. (1). 


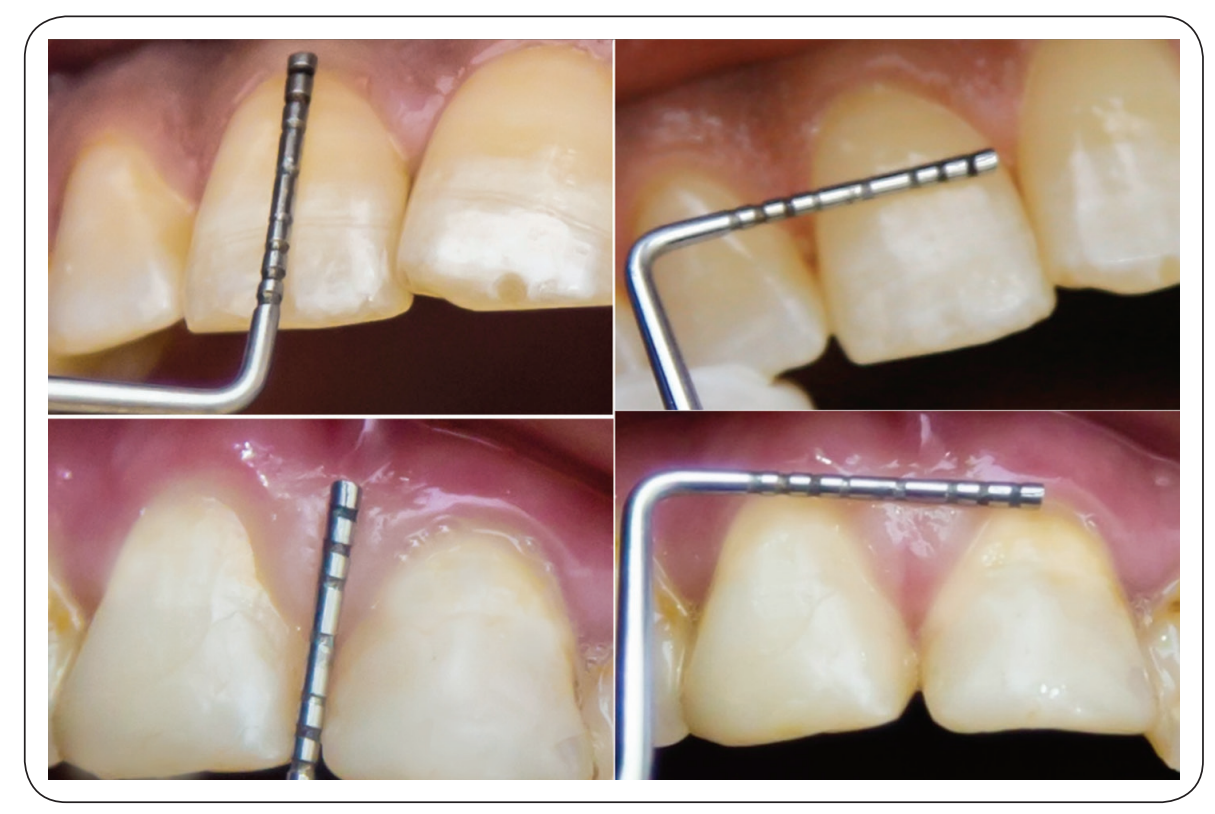

Fig. (1) A clinical photograph showing clinical crown length, crown width, Papillary height and papillary width.

\section{Radiographic Parameters}

\section{1) Facial gingival thickness}

An impression was taken for each patient and special stent was fabricated with $0.5 \mathrm{~mm}$ wire adapted to the fitting surface at the reference point which is $1 \mathrm{~mm}$ from the gingival margin the fabricated stent was applied to the facial surface of maxillary anterior teeth before the CBCT scan the gingival thickness was measured as the distance between inner surface of the wire to the facial surface of the tooth Fig. (2).

\section{2)Thickness of buccal alveolar bone}

Measurements of buccal bone thickness were performed at a reference points: $1 \mathrm{~mm}$ from the alveolar crest at the mid-buccal aspect of each tooth, perpendicular to the axis of the tooth. Fig. (2).

\section{Statistical analysis}

The data was collected, tabulated, computed and statically analyzed to include the following: The mean and standard deviation values were calculated for each group. Data were explored for normality using Kolmogorov-Smirnov and Shapiro-Wilk tests.
Data showed parametric (normal) distribution, Pearson correlation was used to find the correlation between Gingival thickness and each of Bone thickness, Crown length, Crown width, Papillary height and Papillary width. Independent sample t-test was used to compare between females and males' results in each variable. The significance level was set at $P \leq 0.05$. Statistical analysis was performed with IBM $®$ SPSS $®$ Statistics Version 20 for Windows.

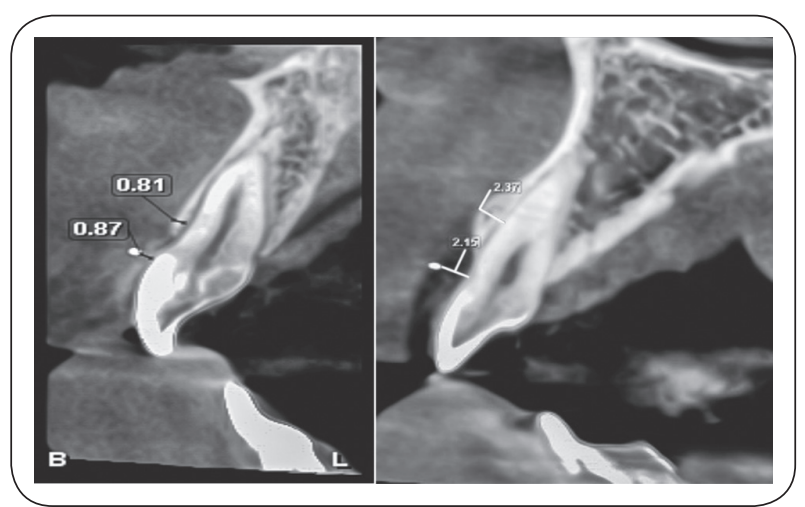

Fig. (2) Showing radiographic photo for thin and thick gingival thickness and bone thickness measurements 


\section{RESULTS}

The mean and standard deviation values were calculated for each group. Data were explored for normality using Kolmogorov-Smirnov and ShapiroWilk tests. Data showed parametric (normal) distribution.

Pearson correlation was used to find the correlation between Gingival thickness and each of Bone thickness, Crown length, Crown width, Papillary height and Papillary width. Independent sample t-test was used to compare between females and males' results in each variable.

A statistically significant difference was found between females and males in all variables Gingival thickness, Bone thickness, Crown length, Crown width, Papillary height and Papillary width where respectively, where females always showed thin type (table 1).

Correlation between Gingival thickness with (Bone thickness, crown length, crown width, Papillary height and papillary width).

There was a significant positive relationship between Gingival thickness, Bone thickness, Crown width and Papillary width and there was a significant negative relationship between Gingival thickness and Crown length and Papillary height. Table (2), figure (3).

Table (1): Demographics of all groups:



Table (2): Correlation between Gingival thickness with (Bone thickness, crown length, crown width, Papillary height and papillary width).

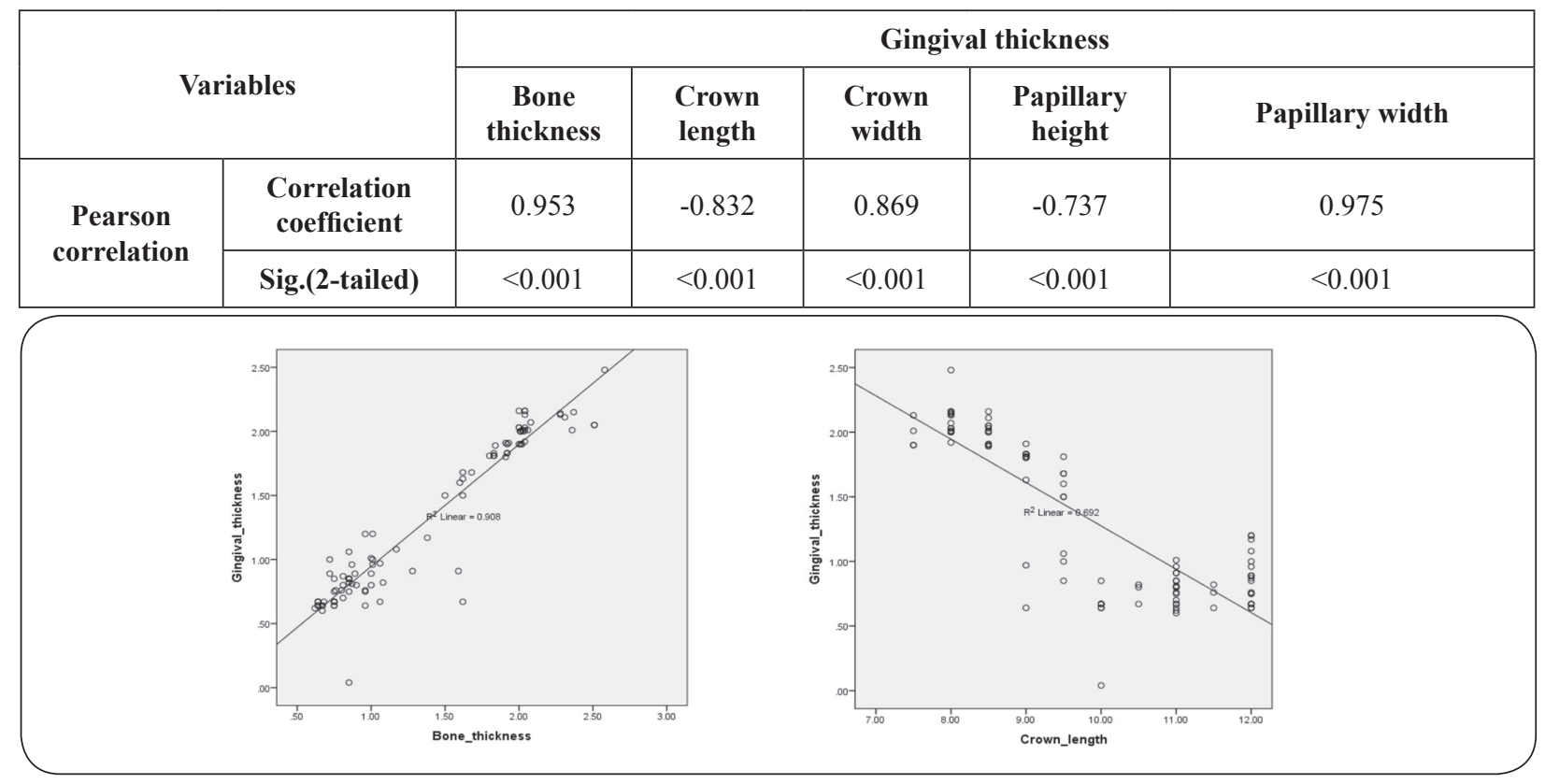




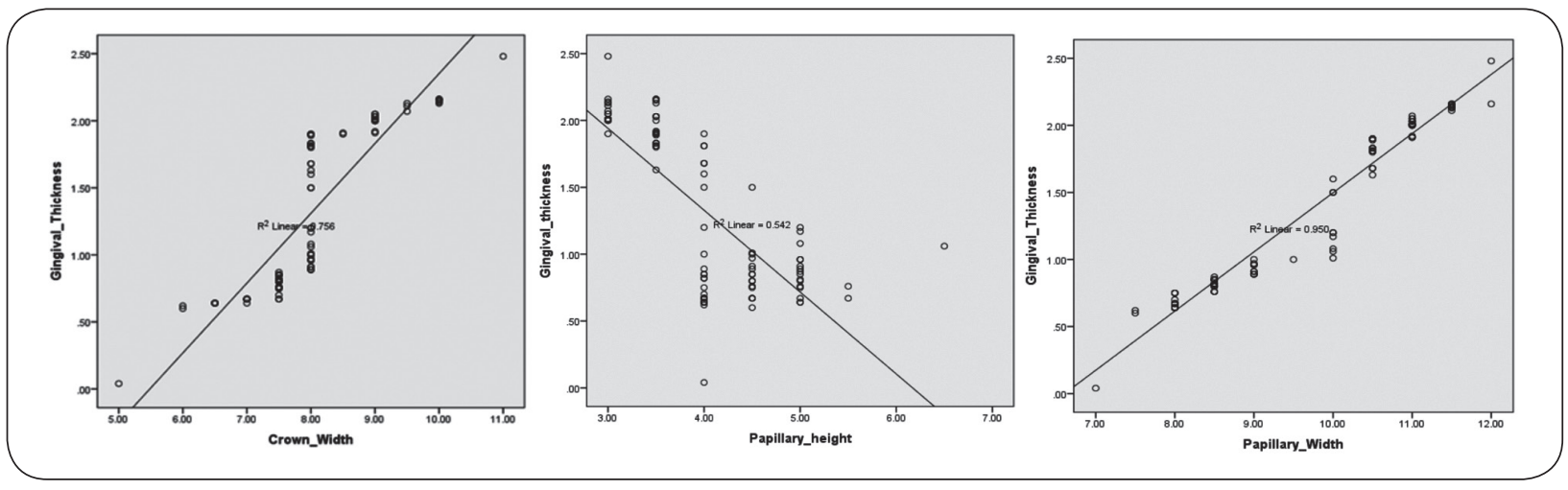

Fig. (3): Bar chart representing correlation between gingival thickness with (Bone thickness, crown length, crown width, Papillary height and papillary width).

\section{DISCUSSION}

Tissue biotype is one of the critical factors that pave the way to the result of dental treatment. In recent years, the dimension gingival thickness has become the subject of considerable interest. The prediction of gingival biotype would provide the predictable outlook of future recession Hwang (2006) ${ }^{15}$.

Accurate measurements of the soft and hard tissue dimensions are important because they affect the outcomes of periodontal treatment, particularly in aesthetically critical areas. Therefore, the maxillary anterior regions have frequently been analyzed, with the goal of developing reliable guidelines for the identification of critical cases with thin gingiva and/or alveolar bone Januário et al (2011) ${ }^{10}$ and Nikiforidou et al (2016) ${ }^{24}$

Only maxillary central incisors were included as reference teeth because differences between biotypes are most explicit for these teeth and because their specific features are easily found in other parts of the dentition. The shape of the central incisor seems to distinguish between different periodontal biotypes also around other teeth in the same dentition So, the tooth morphology appears to be correlated with the soft tissue quality Olsson, Lindhe (1993) ${ }^{8}$.

Several methods have been used to measure the thickness of gingival tissue Roney et al $(2011)^{25}$ among which are Manual assessment using a caliper after tooth extraction $\mathrm{Fu}$ et al $(2010)^{3}$, a syringe with endodontic depth marker Olsson et al $(1993)^{8}$, the direct method or transgingival probing kan et al (2003) ${ }^{21}$, ultrasonic devices Muller et al (2000) ${ }^{26}$, and more recently, Cone-Beam Computed Tomography (CBCT) Barriviera , Janu'ario et al (2011) ${ }^{10}$.

The direct technique had been used by Kan et al (2003) ${ }^{21}$ and La Rocca et al (2012) ${ }^{12}$ to determine the gingival biotype by using of Periodontal probe, injection needle or an endodontic tool, this method has inherent limitations, such as precision of the probe, the angulation of the probe and distortion of tissue during probing in addition, this method is inconvenient for the patient because it is invasive and must be performed under local anesthesia. Furthermore, it is sometimes difficult to precisely determine the position of a few structures such as the CEJ and the bone crest.

To overcome these limitations, noninvasive methods were devised the ultrasonic devices and cone beam computed tomography but these methods are technique sensitive and quite expensive.

In a study done by Younes et al (2016) ${ }^{27}$ ultrasonic devices have been proposed to measure gingival thickness Although such ultrasonic methods are noninvasive and exhibit good reliability but their ability to accurately determine the thickness of a 
specific site is limited and the unavailability and a high cost of the device limit the use of this method.

A novel technique utilizing CBCT images and that consistently produced images that allowed soft and hard tissue dimensions to be measured at identical levels using this simple and noninvasive technique Compared with other recent studies this method was associated with a smaller possibility of errors Younes et al (2016) ${ }^{27}$ and Sanz Martin et al (2016) ${ }^{28}$. From this point, the present study used clinical and CBCT radiographical analysis for all selected patients.

In the present study, CBCT was used to visualize and measure thickness of both hard and soft tissues. Various authors reported that CBCT measurements of both bone and labial soft tissue thickness are accurate and concluded that CBCT measurements might be a more objective method to determine the thickness of both soft and hard tissues than direct measurements. In contrast to transgingival probing and the ultrasonic device, CBCT method provides an image of the tooth, gingiva, and other periodontal structures. Moreover, measurements can be repeatedly taken at different times with the same image obtained by ST-CBCT (soft tissue CBCT) which is not feasible by another methods $\mathrm{Fu}$ et al (2010) ${ }^{3}$, Nikiforidou et al (2016) ${ }^{24}$ and Younes et al (2016) ${ }^{27}$

In ST-CBCT by Barriviera, Janu'ario et al $(2011)^{10}$, this technique, two separate CBCT scans were obtained; the first was a scan following standard methods; however, for the ST-CBCT the patients wore a plastic lip retractor and retracted their tongues toward the floor of their mouths. With the first scan, only measurements of the distance of the cementoenamel junctional (CEJ) to the facial bone crest, and the width of the facial alveolar bone were possible. In contrast, ST-CBCT allowed width of the facial gingiva, in this technique patient exposed to more radiation by obtained two CBCT scan to differentiated and create space between the lip and gingiva in the second exposure. So that the present study used a new technique by fabrication of special stent lined by $0.5 \mathrm{~mm}$ wire in the fitting surface to clear the facial margin of the gingiva as the space between the wire and tooth surface for CBCT scan to measure Facial gingival thickness and buccal alveolar bone Thickness.

In our study we take the clinical parameters (measurements) which concern the maxillary central incisors and adjacent gingiva using a standardized periodontal probe including: Clinical Crown length, Crown width, Papillary height and Papillary height. On another hand we make.

The aim of this study was to measure buccal bone thickness and gingival thickness using a noninvasive and relatively accurate digital registration method as well as to determine a possible relationship between hard and soft tissue thickness and between clinical and radiographic parameters.

The result of the present study reviled statistically significant correlation between the gingival biotype, bone thickness, Crown length, crown width and papilla of anterior incisor crowns and respectively most females showed thin biotype than males. These results in agreements with Manjunath et al (2015) ${ }^{29}$, who compared the gingival biotype among different age groups in men and women and stated that thick biotype was more in males than females.

The results of the present study reported that as the tooth crown length increased and width decreased the gingiva is exhibited to be thin i.e. the gingival thickness show a negative correlation with crown length and positive correlation with crown width. These result in accordance to Ochsenbein and Ross (1969) ${ }^{5}$. They believed that long-tapered teeth tend to have a thin-scalloped periodontium, whereas wide-square teeth have thick-flat periodontia and Olsson and Lindhe $(1991)^{7}$, proposed that long-narrow teeth are more susceptible to GR than short-wide teeth because of the difference in periodontal biotype.

The results of the present study reported that as the tooth papillary height increased and width decreased the gingiva is exhibited to be thin i.e. the 
gingival thickness show a negative correlation with crown length and positive correlation with crown width. These result in accordance to Anand et al (2012) ${ }^{30}$ Manjunath et al (2015) ${ }^{29}$ which reported that, the thick biotype exhibited short and flat papillae, whereas thin biotype showed long and scalloped papillae.

The linear regression analysis of the present study demonstrated a positive moderate correlation between the radiographic thickness of the labial gingiva and its underlying bone. The mean gingival thickness at the central incisors was $1.38 \mathrm{~mm}$ and the buccal bone thickness was $1.31 \mathrm{~mm}$.

These findings are in agreements with the results published by Fu et al (2010) ${ }^{3}$. In this study, 22 cadaver heads were subject to investigation. A moderate correlation $(\mathrm{R}=0.429 ; \mathrm{p}=0.001)$ between the buccal soft and hard tissue thickness. And a perfect match of the hard and soft tissue findings by Stein et al (2013) ${ }^{31}$ performed a comparative study of 60 subjects and reported a positive correlation between buccal bone thickness and gingival thickness.

\section{CONCLUSIONS}

1. By understanding the nature of tissue biotypes, clinicians can employ appropriate periodontal management to minimize alveolar resorption and provide more favorable results after dental treatment.

2. Cone beam computed tomography CBCT appeared to be non-invasive attractive and accurate method to determine the gingival biotype with its precise measurement.

3. The gingival thickness exhibit a significance positive relationship with bone thickness, crown and papillary width.

4. The gingival thickness exhibit a significance negative relationship with crown length and papillary height.

5. Gingival biotype looked to be thin in females than males.

6. These findings can be utilized in the planning and execution of various periodontal and dental surgical procedures with increase predictability.

\section{REFERENCE}

1. Zigdon $\mathrm{H}$ and Machtei EE. The dimensions of keratinized mucosan around implants affect clinical and immunological parameters. Clin Oral Implants Res. 2008;19:387-92.

2. Rouck De, Eghbali T, Collys R et al. Thevgingival biotype revisited: Transparency of the periodontal probe through the gingival margin as a method to discriminate thin from thick gingiva. J Clin Periodontol. 2009; 36:428-33.

3. Fu JH, Yeh CY, Chan HL et al. Tissue biotype and its relation to the underlying bone morphology. J Periodontol. 2010; 81:569-74.

4. Ranjan M, Vishakha G, Arvind B et al. Analysis of the gingival biotype based on the measurement of the dentopapillary complex. J Ind Soci of Periodent. 2016; 18.

5. Ochsenbein $\mathrm{C}$ and Ross S. A reevaluation of osseous surgery. Dent Clin North Am. 1969; 13: 87-102.

6. Seibert $\mathrm{J}$ and Lindhe J. Esthetics and periodontal therapy. In: Textbook of Clinical Periodontology, (ed.) J. Lindhe, 2nd edition, pp. 1989;477-514. Copenhagen: Munsgaard.

7. Olsson $\mathbf{M}$ and Lindhe J. Periodontal characteristics in individuals with varying form of the upper central incisors. J Clin Periodontol 1991; 18: 78-82.

8. Olsson M, Lindhe J, Marinello CP. On the relationship between crown form and clinical features of the gingiva in adolescents. J Clin Periodontol. 1993;20: 570-577.

9. Lee SL, Kim HJ, Son M et al. Anthropometric analysis of maxillary anterior buccal bone of Korean adults using cone-beam. CT. J Adv Prosthodont. 2010; 2:92-96.

10. Januario AL, Duarte WR, Barriviera M et al. Dimension of the facial bone wall in the anterior maxilla: a cone-beam computed tomography study. Clin Oral Implants Res. 2011; 22:1168-1171.

11. Nowzari H, Molayem S, Chiu $\mathrm{CH}$ et al. Cone Beam Computed Tomographic Measurement of Maxillary Central Incisors to Determine Prevalence of Facial Alveolar Bone Width $>/=2 \mathrm{~mm}$. Clin Implant Dent Relat Res. 2012;14: 595-602.

12. Rocca La, Alemany AP, Levi, AS et al. Anterior maxillary and mandibular biotype: relationship between gingival thickness and width with respect to underlying bone thickness. Implant Dent. 2012; 21, 507.

13. Baldi C, Pini-Prato G, Pagliaro U et al. Coronally advanced flap procedure for root coverage. Is flap thickness a relevant predictor to achieve root coverage? A 19-case series. J Periodontol. 1999; 70:1077-1084. 
14. Evans CD and Chen ST. Esthetic outcomes of immediate implant placements. Clin Oral Implants Res. 2008;19: 73-80.

15. Hwang D and Wang HL. Flap thickness as a predictor of root coverage: a systematic review. J Periodontol. 2006; $77: 1625-1634$.

16. Belser U, Buser D, Higginbottom F. Consensus statements and recommended clinical procedures regarding esthetics in implant dentistry. Int J Oral Maxillofac Implants. 2004; 19:73-74

17. Garber DA and Salama MA. The aesthetic smile: diagnosis and treatment. Periodontol. 1996;11: 18-28.

18. Levin R. The challenge of esthetic dentistry and elective services. J Am Dent Assoc 2005; 136:515-516.

19. Botticelli D, Berglundh T, Lindhe J. Hard-tissue alterations following immediate implant placement in extraction sites. J Clin Periodontol. 2004; 31: 820-828.

20. Eghbali A, Rouck De, Bruyn H. The gingival biotype assessed by experienced and inexperienced clinicians. J Clin Periodontol 2009;36.

21. Kan JY, Rungcharassaeng K, Umezu K. Dimensions of periimplant mucosa: an evaluation of maxillary anterior single implants in humans. J Periodontol. 2003;74: 557-562.

22. Claffey $\mathrm{N}$ and Shanley D. Relationship of gingival thickness and bleeding to loss of probing attachment in shallow sites following nonsurgical periodontal therapy. $\mathrm{J}$ Clin Periodontol. 1986 ;13: 654-657.

23. Muller HP, Schaller N, Eger T. Ultrasonic determination of thickness of masticatory mucosa: a methodologic study.
Oral Surg Oral Med Oral Pathol Oral Radiol Endod. 1999; 88: $248-253$

24. Nikiforidou M, Tsalikis L, Angelopoulos C, Menexes G, Vouros I, Konstantinides A. Classification of periodontal biotypes with the use of CBCT. A cross-sectional study. Clin Oral Investig. 2016; 20:2061-71.

25. Ronay V, Sahrmann P, Bindl A et al. Current status and perspectives of mucogingival soft tissue measurement methods. $\mathbf{J}$ Esthet Restor Dent. 2011; 23:146-56.

26. Muller HP, Schaller N, Eger $\mathrm{T}$ et al. Thickness of masticatory mucosa. J Clin Periodontol. 2000; 27:431436. Clin Periodontol. 2008; 36:564-568

27. Younes F, Eghbali A, Raes M, et al. Relationship between buccal bone and gingival thickness revisited using noninvasive registration methods. Clin Oral Implants Res. 2016; 27:523-8.

28. Sanz Martin I, Benic GI, Hämmerle CH et al. Prospective randomized controlled clinical study comparing two dental implant types: volumetric soft tissue changes at 1 year of loading. Clin Oral Implants Res. 2016; 27: 406-11.

29. Manjunath RG, Rana A, Sarkar A et al. Gingival biotype assessment in a healthy periodontium: Transgingival probing method. J Res. 2015; 9:66-9.

30. Anand V, Govila V, Gulati M. Correlation of gingival tissue biotypes with gender and tooth morphology: A randomized clinical study. Indian J Dent 2012; 3: 190-5.

31. Stein JM, Lintel-Höping N, Hammächer C et al. The gingival biotype: measurement of soft and hard 


\section{مجلة أسيوط لطب الأسنان}

النشر الرسمي لكلية طب الأسنان

جامعة الأزهر أسيوط لكاط طان

مصر جامع

AADJ, Vol. 2, No. 1, April (2019) - PP. 9

الملخص العربي

الغرض:

خديد العلاقة بين سـماكة اللثة و (سمكك عظم الفكك الظاهري ، طول التاج ، عرض التاج ، ارتفاع الحلمية اللثوية وعرض الحليمية اللثوية)

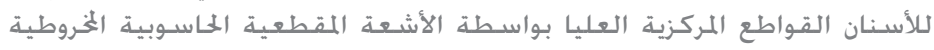

الموضوعات والأساليب

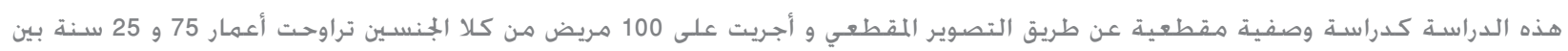

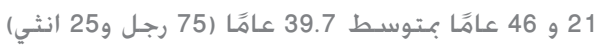



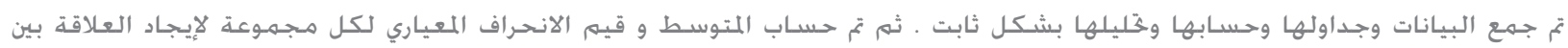



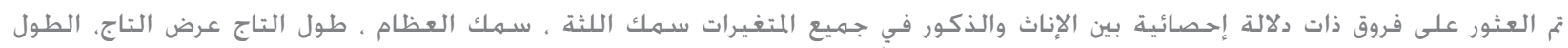

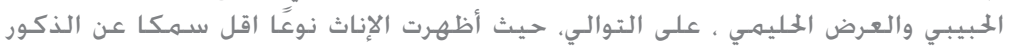

كانت هناك علاقة إيجابية معنوية بين سـماكة اللثة وسـماكة العظام ، والتي تنص على أن زيادة سمكك اللثة سيصاحبها زيادة في سـماكة



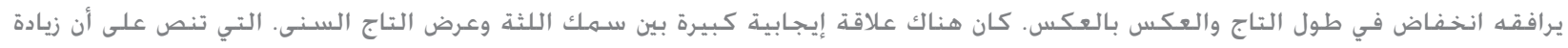

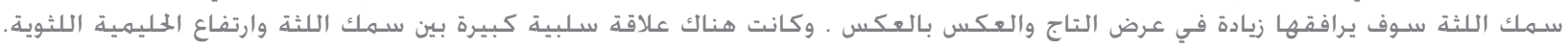

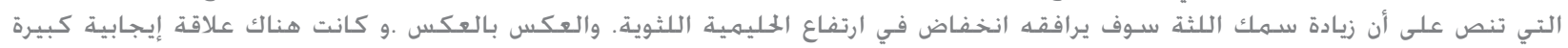
بين سـمك اللثة وعرض الحليمية اللثوية. التي تنص على أن زيادة سـمك اللثة سـوف يرافقها زيادة في عرض الحليمية الحسية اللثوية والعكس بالعكس

| (لاستنتاجات:

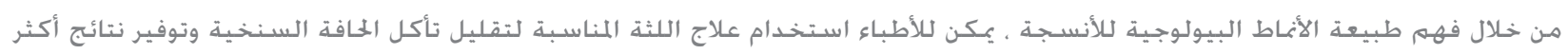

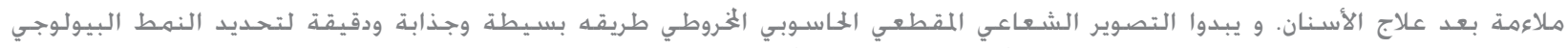

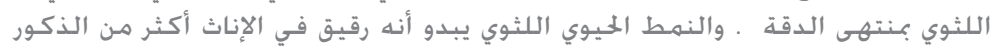

الكلمات الرئيسية:

التصوير الشعاعي المقطعي الحاسوبي الخخروطي ، اللثة،سماكة العظم ،سماكة عرض التاج .العرض الحليمي اللثوي، طول التاج والارتفاع الحليمي اللثوى 